\title{
COLORED POLYETHYLENE SOIL COVERS AND GRAFTING EFFECTS ON CUCUMBER FLOWERING AND YIELD
}

\author{
Inês Cristina de Batista Fonseca ${ }^{1 *}$; Antonio Evaldo Klar²; Rumy Goto ${ }^{3}$; Carmen Silvia Vieira \\ Janeiro Neves ${ }^{1}$ \\ ${ }^{1}$ UEL - Depto. de Agronomia, C.P.6001 - 86051-990 - Londrina, PR - Brasil. \\ ${ }^{2}$ UNESP/FCA - Depto. de Engenharia Rural, C.P.237 - CEP: 18603-970 - Botucatu, SP - Brasil. \\ ${ }^{3}$ UNESP/FCA - Depto. de Produção Vegetal. \\ * Corresponding author <inescbf@uel.br>
}

\begin{abstract}
Cucumber (Cucumis sativus L.) is one of the most cultivated vegetable crops in plastic greenhouses in Brazil because of the short cycle and its high economic value in off-season harvests. To better understand this management technique the effect of different colored polyethylene soil covers was evaluated in relation to flowering and yield of the hybrid cucumber 'Yoshinari' grafted or not on the hybrid squash 'Ikky'. The polyethylene cover colors were black, white on black and green plus a control without cover. Covered but not grafted crops had a more uniform flowering distribution. The number of flowers was greater for the white/black grafted treatment. All the polyethylene covers favored flowering for the non grafted plants. Grafting reduced flowering for the black or green polyethylene covers treatments. The fruit set increased with the use of polyethylene cover but was not influenced by grafting. The uniform distribution of flowering remained during fruiting only for grafted plants and soil covered with black or green polyethylene. Both polyethylene cover and grafting favored early harvesting. The 'Yoshinari'/'Ikky' graft caused taller plants but fruit were thicker and smaller and did not meet the commercial standard. The best quality fruit and highest yields were obtained in the black and white/black treatments, without grafting.
\end{abstract}

Key words: Cucumis sativus, Cucurbita spp., plastic greenhouse, rootstock

\section{FLORESCIMENTO E PRODUÇÃO DE PEPINO JAPONÊS EM FUNÇÃO DE CORES DE COBERTURA DE SOLO E ENXERTIA}

\begin{abstract}
RESUMO: O pepino (Cucumis sativus L.) é, dentre os produtos hortícolas, um dos mais visados para o cultivo em estufas no Brasil devido ao ciclo vegetativo curto e ao elevado valor econômico no período da entressafra. Estudou-se, em condições de ambiente protegido, a influência de diferentes cores de cobertura plástica de solo no florescimento e na produção de pepino híbrido 'Yoshinari' enxertado ou não sobre abóbora híbrida 'Ikky'. Os tratamentos de cobertura foram: preto, preto pintado de branco, verde, e sem cobertura. Os tratamentos cobertos com plástico e sem enxertia apresentaram florescimento com distribuição mais uniforme na planta. O número de flores foi superior no tratamento preto/branco enxertado. Para as plantas não enxertadas, todas as coberturas favoreceram o florescimento. A enxertia favoreceu o florescimento somente para os tratamentos com plástico preto ou verde. A fixação dos frutos aumentou pelo uso de cobertura plástica, mas a enxertia não teve influência. A distribuição uniforme do florescimento manteve-se na frutificação apenas para os tratamentos com plantas enxertadas e cobertura do solo com plástico preto ou verde. Tanto o uso de cobertura plástica quanto a enxertia favoreceram a colheita precoce. Os frutos de melhor qualidade e as maiores produções, em número de frutos, foram obtidos nos tratamentos preto e preto/branco, não enxertados. A enxertia 'Yoshinari'/'Ikky' provocou o aparecimento de frutos mais grossos e menores, fora do padrão de comercialização.

Palavras-chave: Cucumis sativus, Cucurbita spp., ambiente protegido, porta-enxerto
\end{abstract}

\section{INTRODUCTION}

Cucumber is one of the most cultivated vegetable crops in plastic greenhouses in Brazil because of its short cycle and high economic value in off-season harvests. Polyethylene soil cover is used to protect the crop and the soil, as it prevents erosion and drying, improves fruit quality, reduces extreme thermal variations and also makes hoeing and herbicides unnecessary. The use of different colors of polyethylene as soil cover for cucumber has been used mainly in other countries. The crop varies in response to polyethylene mulch covers depending on cultivar, materials used and environmental conditions (Bhella, 1988; Wolfe et al., 1989; Salman et al., 1991; Quezada-Martin et al., 1992). There are few reports on this subject for Brazilian conditions. 
Cucumber grafting has the benefit of conferring resistance to soil pathogens and enhanced yield (PerezAfonso, 1984; Cañizares \& Goto, 1998). This technique, however, is still little used in commercial production and requires further study. To assess the influence of different colors of polyethylene cover on flowering and yield responses, a trial was carried out with the cultivar Yoshinari, under greenhouse conditions. Grafting of this cultivar on the squash hybrid 'Ikky' was also made.

\section{MATERIAL AND METHODS}

The experiment was carried out in the Fall of 1995 (between April and June) in Botucatu, SP, 22 51'S and $48^{\circ} 26^{\prime} \mathrm{W}$, altitude $786 \mathrm{~m}$, on an medium/clay textured Haplustalf intergrade to Eutrorthox. The climate of the region is of type Cfa according to the Köeppen's classification (humid subtropical; no dry season, mean temperature of coldest month $<18^{\circ} \mathrm{C}$; mean temperature of hottest month $>22^{\circ} \mathrm{C}$ ). Greenhouse mean temperatures during the experimental period were $21.6 ; 19.8$ and $18^{\circ} \mathrm{C}$ respectively, for April, May and June. Soil chemical analysis of the 0-20 cm layer indicated: $\mathrm{pH}\left(\mathrm{CaCl}_{2}\right)=5.4$; org. mat. $=15 \mathrm{~g} \mathrm{dm}^{-3} ; \mathrm{P}=26 \mathrm{mg} \mathrm{dm}^{-3} ; \mathrm{K}^{+}=3.4 \mathrm{mmol} \mathrm{dm}^{-3}$; $\mathrm{Ca}^{+2}=26 \mathrm{mmol}_{\mathrm{c}} \mathrm{dm}^{-3} ; \mathrm{Mg}^{+2}=11 \mathrm{mmol}_{\mathrm{c}} \mathrm{dm}^{-3} ; \mathrm{H}^{+}+\mathrm{Al}^{3+}$

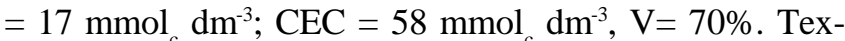
tural characteristics were yielded $460 \mathrm{~g} \mathrm{~kg}^{-1}$ clay, $110 \mathrm{~g}$ $\mathrm{kg}^{-1}$ silt and $430 \mathrm{~g} \mathrm{~kg}^{-1}$ sand. The crop was fertilized according to the chemical analysis and recommendations for the crop.

The crop was grown in a $8 \mathrm{~m}$ wide and $24 \mathrm{~m}$ long plastic greenhouse with a metallic semicircular arched roof covered with a $0.075 \mathrm{~mm}$ thick clear polyethylene film. The sides consisted of shading screens and plastic film curtains that were closed when there was risk of rain. The soil was prepared through plowing and tilling, and the plots were prepared by hand. The hybrid cucumber 'Yoshinari' was used and the 'Ikky' hybrid squash (Cucurbita spp.), bloom less type, was used as rootstock. Sowing and grafting were carried out in trays and plants were transplanted on April 4. Beds were $0.8 \mathrm{~m}$ wide, 20 $\mathrm{m}$ long and $1 \mathrm{~m}$ apart. Plants were placed in the center of the beds at a distance of $0.6 \mathrm{~m}$ between plants.

Plants were trained and pruned by removing the side shoots and flowers up to the 4 th internode. Side shoots were preserved from this point on, but they were pruned, leaving two internodes. The apex bud was removed at the 20th node on the non grafted plants and at the 24th node on the grafted plants, at the height of 1.2 $\mathrm{m}$ for all treatments. Tertiary buds were removed by pruning. Harvesting began 30 days after transplant. All treatments received the same amount of water, calculated using tensiometer readings.

Treatments consisted of: BG: black polyethylene cover and grafted plants; BNG: black polyethylene cover and non-grafted plants; WG: white on black (white/black) polyethylene cover and grafted plants; WNG: white on black (white/black) polyethylene cover and non-grafted plants; GG: green polyethylene cover and grafted plants GNG: green polyethylene cover and non-grafted plants; NMG: no cover and grafted plants; NMNG: no cover and non-grafted plants.

The following traits were scored weekly after the first female flowers appeared (24 April): height of main stem, number of female flowers; position of female flowers - on central stem (CS), on the first node of the side branches (B1) and on the second node of the side branches (B2). Fruit were harvested every two days starting on 5 May. The following traits were assessed: percentage of viable fruit, fruit position (CS, B1 or B2), weight, length, diameter and commercial classification. The following criteria were adopted for this classification: Extra AA: Length $(\mathrm{L})=20.5-23.5 \mathrm{~cm}$ and transversal diameter $(\mathrm{TD})<3.0 \mathrm{~cm}$. Extra A: $\mathrm{L}=22.5-25.5 \mathrm{~cm}$ and $\mathrm{TD}<3.5 \mathrm{~cm}$. Extra: $\mathrm{L}=20.5-23.5 \mathrm{~cm}, \mathrm{TD}<3 \mathrm{~cm}$ and deformity; $\mathrm{L}=22.5-25.5 \mathrm{~cm}, \mathrm{TD}<3.5 \mathrm{~cm}$ and deformity; L > $25.5 \mathrm{~cm}$, with or without deformity; Special: $\mathrm{L}=17.0-20.4 \mathrm{~cm}$, $\mathrm{TD}<3.05 \mathrm{~cm}$, no deformity; $\mathrm{L}=20.5-22.4 \mathrm{~cm}$, TD $>3.05 \mathrm{~cm}$, with or without deformity; $\mathrm{L}=22.5-25.5 \mathrm{~cm}$, TD $>3.55 \mathrm{~cm}$, with or without deformity; L $>25.5 \mathrm{~cm}$, TD $>4.05 \mathrm{~cm}$, with or without deformity; Discard: $\mathrm{L}=\langle 17.0 \mathrm{~cm}$, with or without deformity; $\mathrm{L}=17.0-20.4 \mathrm{~cm}$, TD $>3.0 \mathrm{~cm}$, with deformity. In order to compare fruit quality among treatments this classification was converted to scores, calculated attributing values to the percentages of fruit of each classification, in other words, the percentage of discarded fruit received value 1 , the percentage of special fruit received value 2 and so on. The values were added and a score by plant was obtained. The mean number of days from transplant to harvest for each treatment was also calculated.

A complete randomized block design was used, with treatments in a $4 \times 2$ factorial scheme (four types of polyethylene cover $\mathrm{x}$ two types of graft) with four replications. Each plot contained four plants, and the two central ones were evaluated. Analysis of variance was performed and means were compared by the Tukey test. The tests were for unbalanced data, according to Mischan \& Pinho (1996) as the experiment became unbalanced due to the death of four plants. The number of flowers and number of fruit were transformed in $\sqrt{\mathrm{n}}$. The data for fruit set were transformed in arc sen $\sqrt{\mathrm{p} / 100}$ where $\mathrm{p}$ is the percentage of fruiting.

A complete study of $\mathrm{R}$ (row) x $\mathrm{C}$ (column) contingency tables was carried out for $\mathrm{R}>2$ independent samples (treatments) and $\mathrm{C}>2$ classifying variables (Curi, 1997) to verify whether there was an association among treatments and flowering positions (CS, B1 and B2) and if there was, to quantify differences among the 
ratios within each treatment and within each position. The same study was carried out to verify the existence of association among treatments and fruiting positions for the commercial classification of the fruit.

When the interaction between polyethylene cover and grafting was significant, as for plant height at 34 days, total number of female flowers and number of female flowers at B1, the interaction was partitioned.

\section{RESULTS AND DISCUSSION}

At 34 days, plant height was not affected by cover type for grafted plants (Table 1). For the non-grafted, however, cover was superior to no cover, with black = green > white/black. Salman et al. (1991), Quezada-Martin et al. (1992) and Hallidri et al. (2001) obtained greater plant heights when using polyethylene. This probably occurred in the present study because all the treatments received equal amounts of irrigation water and the polyethylene covers, reduced evapotranspiration.

The white on black polyethylene cover produced the highest total number of female flowers (Table 1) while the green polyethylene cover produced the lowest total for the grafted plants. In the case of non-grafted plants, all polyethylene treatments produced equal number of female flowers, which was 1.8 times larger than for the no cover treatment. The number of flowers on the central stem was greatest using the white/black polyethylene cover but less when the green polyethylene cover was used. The results for the number of flowers in B1 were similar to those observed in the assessment of the total number of flowers. The black and white/black polyethylene cover treatments performed best for the number of flowers on B2.

Total fruit set in all the polyethylene covers were higher than in the no cover treatments and also for fruit set on the CS. These results may be linked to water use since the polyethylene covers reduce water loss and more water is available for fruit formation. Polyethylene covers did not influence fruit set at B1 or B2.

The highest yield (total number of fruit) was obtained with the black or white/black polyethylene covers (Table 1). The lowest yield was for the no cover treatment and the green polyethylene cover had intermediate performance. The number of fruit on CS, B1 and B2 was similar to the total number of fruit. This increase in yield

Table 1 - Flowering and fruiting characteristics of 'Yoshinari' cucumber plants submitted to soil covering and grafting treatments. Botucatu, SP, 1995.

\begin{tabular}{|c|c|c|c|c|c|}
\hline \multirow[b]{2}{*}{ Characteristic } & \multirow[t]{2}{*}{ C.V.\% } & \multicolumn{4}{|c|}{ Cover type } \\
\hline & & Black & Black / White & Green & No cover \\
\hline $\begin{array}{l}\text { Plant height } 34 \text { days } \\
\text { - Grafted plants }(\mathrm{cm}) \\
\text { - Non-grafted plants }(\mathrm{cm})\end{array}$ & 27.58 & $\begin{array}{l}115.54 \mathrm{Aa}^{1} \\
128.57 \mathrm{Aa}\end{array}$ & $\begin{array}{r}102.29 \mathrm{Aa} \\
66.38 \mathrm{Abc}\end{array}$ & $\begin{array}{l}96.00 \mathrm{Aa} \\
86.86 \mathrm{Aab}\end{array}$ & $\begin{array}{l}94.50 \mathrm{Aa} \\
42.00 \mathrm{Bc}\end{array}$ \\
\hline $\begin{array}{l}\text { Total number of female flowers per plant } \\
\text { - Grafted plants } \\
\text { - Non-grafted plants }\end{array}$ & 14.90 & $\begin{array}{l}43.57 \mathrm{Bab} \\
67.14 \mathrm{Aa}\end{array}$ & $\begin{array}{l}55.00 \mathrm{Aa} \\
59.00 \mathrm{Aa}\end{array}$ & $\begin{array}{l}28.63 \mathrm{Bb} \\
51.38 \mathrm{Aa}\end{array}$ & $\begin{array}{l}48.33 \mathrm{Aab} \\
32.50 \mathrm{Ab}\end{array}$ \\
\hline $\begin{array}{l}\text { Number of female flowers in } \mathrm{B}^{2} \\
\text { - Grafted plants } \\
\text { - Non-grafted plants }\end{array}$ & 22.61 & $\begin{array}{l}14.43 \mathrm{Bab} \\
27.71 \mathrm{Aa}\end{array}$ & $\begin{array}{l}18.00 \mathrm{Aa} \\
20.88 \mathrm{Aa}\end{array}$ & $\begin{array}{r}8.25 \mathrm{Bb} \\
19.00 \mathrm{Aa}\end{array}$ & $\begin{array}{c}15.00 \mathrm{Aab} \\
8.50 \mathrm{Ab}\end{array}$ \\
\hline Number of female flowers in CS & 11.49 & $21.00 \mathrm{ab}$ & $24.88 \mathrm{a}$ & $17.75 \mathrm{~b}$ & $20.86 \mathrm{ab}$ \\
\hline Number of female flowers in B2 & 31.30 & $13.29 \mathrm{a}$ & $12.69 \mathrm{a}$ & $8.63 \mathrm{ab}$ & $7.14 \mathrm{~b}$ \\
\hline Total fuit set $(\%)$ & 12.54 & $46.01 \mathrm{a}$ & $43.36 \mathrm{a}$ & $44.78 \mathrm{a}$ & $33.37 \mathrm{~b}$ \\
\hline Fuit set in CS (\%) & 16.56 & $51.30 \mathrm{a}$ & $52.12 \mathrm{a}$ & $54.03 \mathrm{a}$ & $39.26 \mathrm{~b}$ \\
\hline Fuit set in $\mathrm{B} 1(\%)$ & 39.78 & $49.67 \mathrm{a}$ & $36.80 \mathrm{a}$ & $41.09 \mathrm{a}$ & $37.60 \mathrm{a}$ \\
\hline Fuit set in $\mathrm{B} 2(\%)$ & 55.53 & $32.70 \mathrm{a}$ & $36.10 \mathrm{a}$ & $23.90 \mathrm{a}$ & $24.61 \mathrm{a}$ \\
\hline Total number of fruits per plant & 20.11 & $26.00 \mathrm{a}$ & $25.50 \mathrm{a}$ & $18.06 \mathrm{ab}$ & $12.93 \mathrm{~b}$ \\
\hline Number of fruits in CS & 16.93 & $10.79 \mathrm{ab}$ & $13.13 \mathrm{a}$ & $9.69 \mathrm{~b}$ & $8.29 \mathrm{~b}$ \\
\hline Number of fruits in $\mathrm{B} 1$ & 34.85 & $10.00 \mathrm{a}$ & $7.81 \mathrm{a}$ & $5.63 \mathrm{ab}$ & $2.93 \mathrm{~b}$ \\
\hline Number of fruits in $\mathrm{B} 2$ & 57.52 & $5.21 \mathrm{a}$ & $4.50 \mathrm{ab}$ & $2.75 \mathrm{ab}$ & $1.71 \mathrm{~b}$ \\
\hline Mean fruit weight (g) & 7.36 & $148.21 \mathrm{a}$ & 150.19 a & $150.18 \mathrm{a}$ & $143.53 \mathrm{a}$ \\
\hline Fruit length $(\mathrm{cm})$ & 5.21 & $21.43 \mathrm{a}$ & $21.63 \mathrm{a}$ & $20.28 \mathrm{~b}$ & $20.95 \mathrm{ab}$ \\
\hline Fruit diameter $(\mathrm{cm})$ & 5.94 & $3.24 \mathrm{a}$ & $3.25 \mathrm{a}$ & $3.40 \mathrm{a}$ & $3.28 \mathrm{a}$ \\
\hline Days to harvest & 6.94 & $60.6 \mathrm{~b}$ & $61.7 \mathrm{~b}$ & $61.9 \mathrm{~b}$ & $66.2 \mathrm{a}$ \\
\hline
\end{tabular}

${ }^{1}$ Values followed by the same letter, lower case on the line or upper case in the column (between grafted and non-grafted plants) do not differ by the Tukey test $(P<0.05)$.

${ }^{2} \mathrm{CS}=$ Central stem ; B1 = first branch ; B2= second branch. 
caused by polyethylene covering compared with bare ground was also observed in cucumber in Albania (Hallidri et al.; 2001), Mexico (Farias-Larios et al., 1994; Quezada-Martin et al., 1992) and in Brazil (Araújo et al., 1992) and in muskmelon in the USA (Taber, 1993) and in Chile (Bravo \& Ripol, 1986). Bhella (1988) also recorded higher yields in watermelon plants cultivated with polyethylene cover and attributed the yield increase to weed control, favorable soil temperature in the first $5 \mathrm{~cm}$ soil depth (usually 3 to $5^{\circ} \mathrm{C}$ higher than the no cover treatment temperature), higher soil moisture, and reduction in nutrient loss by leaching. Bonanno \& Lamont Jr. (1987) found differences in yield with or without polyethylene mulch only in the coldest year of their study. In the warmer year, the polyethylene cover (black or clear) did not increase yield. The authors attributed this to the difference in air temperature, as the soil temperature was similar in both years. Salman et al. (1991) also observed this difference in response to year effect in 'Katia' hybrid cucumber in Egypt.

Polyethylene color did not influence the total number of fruit per plant (Table 1). The influence of cover color on cucumber yield was observed by Araújo et al. (1992) who tested covering with red and black polyethylene in Brazil, and found that the yield of the 'Vista Alegre' cultivar was greater for the treatment with red polyethylene $\left(60.27 \mathrm{t} \mathrm{ha}^{-1}\right)$, and lower $\left(47.03 \mathrm{t} \mathrm{ha}^{-1}\right)$ with black polyethylene and without cover $\left(42.33 \mathrm{t} \mathrm{ha}^{-1}\right)$. In Mexico, Farias-Larios et al. (1994) obtained highest yield $\left(63.4 \mathrm{t} \mathrm{ha}^{-1}\right)$ of 'Fanci Pack' cucumber with clear polyethylene and intermediate production (44 to $46 \mathrm{t} \mathrm{ha}^{-1}$ ) with white or black polyethylene with the control yielding only $21.6 \mathrm{t} \mathrm{ha}^{-1}$. A similar result was found by Wolfe et al. (1989) with clear polyethylene as compared to black in 'Marketmore 76' cucumber. Rubeiz et al. (1991) observed that 'Lolita' cucumber yield increased on clear polyethylene cover while black polyethylene produced the same yield in relation to the control. On the other hand, Maiero et al. (1987) obtained greater melon production with polyethylene cover, regardless of the color used (black or clear), as compared to plants without cover.

Covering soil surface did not influence mean fruit weight and fruit diameter. The fruit length was greatest in the black and white/black polyethylene cover treatments (Table 1). However, Farias-Larios et al. (1994) obtained largest fruits of 'Fanci Pack' cucumber with white polyethylene cover and smallest fruits with the control; while white polyethylene cover yielded the longest fruits, which did not differ from the clear polyethylene but the shortest fruits were produced by the black polyethylene cover and the control.

The mean number of days to harvest from transplant was influenced by the polyethylene covers, which started producing five to six days before the non-covered plants (Table 1). The earliness induced by polyethylene covers was also observed by Quezada-Martin et al. (1992) in the 'Sprint 440' cucumber cultivar. This is probably related to water saving due to the polyethylene cover, which enables the plant to complete its cycle in a shorter period. Taber (1993) observed that early harvest increased in melon when soil covers were applied as compared to no covering. Furthermore, the author also observed that the clear polyethylene was more effective in early production than the black polyethylene. In Brazil, Araújo et al. (1992) found that red or black polyethylene induced earlier production of 'Vista Alegre' cucumber when compared to the treatment without covering. Furthermore, the authors found that the polyethylene covers also induced earliness of emergence of plants and of the first female flower appearance. On the other hand, Bonanno \& Lamont Jr. (1987) found difference in earliness with or without polyethylene only in cooler years. Polyethylene covers (black or clear) did not increase earliness the next year, which was warmer. The authors attributed this fact to the difference in the air temperature, as the soil temperature was similar during both years.

There was no effect of grafting on plant development, measured in terms of plant height at 34 days for the covered treatments. The effects can be seen in the treatments without polyethylene, in which the grafted plants grew more than the non-grafted plants (Table 1). Grafting on the hybrid squash 'Ikky' increased plant vigor, compensating the water saving caused by the polyethylene covers. Cañizares \& Goto (1998) also observed this greater development when they grafted the hybrid cucumbers 'Nikkey' and 'Ancor 8' on the hybrid squashs 'Ikky' and 'Tetsukabuto'.

Non-grafted plants flowered more with the black and green polyethylene covers, while grafting did not influence the white/black or no covers treatments (Table 1). Grafting caused fewer flowers on B1 and B2 for most of the covered treatments but did not influence the number of flowers on CS (Tables 1 and 2). The total fruit set on CS, B1 and B2 were not influenced by grafting (Table 2).

For yield, grafting on hybrid squash Ikky (Cucurbita spp.) reduced the total number of fruits on B1 and B2 (Table 2). Nijs (1981) obtained increased yield in several varieties and lines of grafted cucumber grafted on Cucurbita ficifolia L. Hoyos-Eschebarria et al. (2001) also observed increase in cucumber yield when grafted on four rootstocks and Cañizares \& Goto (1998) obtained better yields from 'Nikkey' and 'Ancor 8' cucumber when they were grafted on 'Ikky' squash than when they were not grafted. The entire composite plant must be considered in each case, including the particular cultivar used as the scion top, which can modify the influence of the rootstock (Hartmann et al., 1991). The environment in which the particular combination is tested must also be taken into account because it can influence plant perfor- 
mance. Thus the 'Yoshinari' cucumber / 'Ikky' squash combination in the conditions of this study was not successful from the point of view of yield although it produced more vigorous and taller plants.

Grafting produced heavier fruits (Table 2), probably because of the number of fruits produced which was less for the grafted plants. With fewer fruits, plants can transport more photosynthates to fruits and increase their weight. However, grafting caused the formation of thick, short fruits, which do not meet commercial standard.

Grafting favored early production, with a difference of six days between the grafted and non-grafted plants (Table 2). This effect was also observed by Nijs (1981) who measured an increase of up to $200 \%$ in the early yield of several cultivars and lines of cucumber grafted on Cucurbita ficifolia L. On the other hand, grafting on C. maxima, C. maxima x C. moschata, C. pepo e C. ficifolia reduced precocity of cucumber cv. Serena (Hoyos-Echebarria et al., 2001).

The polyethylene cover treatments with grafting on 'Ikky' squash did not influence the proportion of flowers at any of the positions (CS, B1, and B2) (Table 3). Without grafting, however, the treatment without covering had a greater proportion of flowers on CS compen-

Table 2 - Flowering and fruiting characteristics of 'Yoshinari' cucumber plants grafted and non-grafted on 'Ikki' squash. Botucatu, SP, 1995.

\begin{tabular}{lccc}
\hline Characteristic & C.V. $(\%)$ & Grafted plants & Non-grafted plants \\
\hline Number of female flowers in CS & 11.49 & $21.48 \mathrm{a}^{2}$ & $20.81 \mathrm{a}$ \\
\hline Number of female flowers in B2 & 31.30 & $8.28 \mathrm{~b}$ & $12.48 \mathrm{a}$ \\
Total fruit set (\%) & 12.54 & $41.74 \mathrm{a}$ & $42.29 \mathrm{a}$ \\
\hline Fruit set in CS (\%) & 16.56 & $48.40 \mathrm{a}$ & $50.41 \mathrm{a}$ \\
Fruit set in B1 (\%) & 39.78 & $38.38 \mathrm{a}$ & $43.71 \mathrm{a}$ \\
Fruit set in B2 (\%) & 55.53 & $27.60 \mathrm{a}$ & $31.18 \mathrm{a}$ \\
Total number of fruits per plant & 20.11 & $18.45 \mathrm{~b}$ & $22.81 \mathrm{a}$ \\
Number of fruits in CS & 16.93 & $10.45 \mathrm{a}$ & $10.61 \mathrm{a}$ \\
Number of fruits in B1 & 34.85 & $5.34 \mathrm{~b}$ & $7.77 \mathrm{a}$ \\
Number of fruits in B2 & 57.52 & $2.66 \mathrm{~b}$ & $4.39 \mathrm{a}$ \\
Mean fruit weight (g) & 7.36 & $153.5 \mathrm{a}$ & $143.5 \mathrm{~b}$ \\
Fruit length (cm) & 5.21 & $20.20 \mathrm{~b}$ & $21.95 \mathrm{a}$ \\
Fruit diameter (cm) & 5.94 & $3.46 \mathrm{a}$ & $3.15 \mathrm{~b}$ \\
Number of days to harvest & 6.94 & $58.9 \mathrm{~b}$ & $65.9 \mathrm{a}$ \\
\hline
\end{tabular}

${ }^{1} \mathrm{CS}=$ Central stem; B1= first branch; B2= second branch.

${ }^{2}$ Values followed by the same letter on the line do not differ by the Tukey test $(P<0.05)$.

Table 3 - Proportions of female flowers for treatments and flowering positions and total number of female flowers. Botucatu, SP, 1995.

\begin{tabular}{lcccc}
\hline \multirow{2}{*}{ Treatment } & \multicolumn{2}{c}{ Flowering position } & \multicolumn{2}{c}{$\begin{array}{c}\text { Total number of } \\
\text { flowers }\end{array}$} \\
\cline { 2 - 4 } BG $^{2}$ & \multicolumn{1}{c}{$\mathrm{CS}^{1}$} & $\mathrm{~B} 1$ & $\mathrm{~B} 2$ & 305 \\
$\mathrm{BNG}$ & $46.89 \mathrm{ABCa}^{3}$ & $33.11 \mathrm{ABb}$ & $20.00 \mathrm{ABc}$ & 476 \\
WG & $32.35 \mathrm{Dab}$ & $41.18 \mathrm{Aa}$ & $26.47 \mathrm{Ab}$ & 440 \\
WNG & $45.68 \mathrm{ABCa}$ & $32.73 \mathrm{ABb}$ & $21.59 \mathrm{ABc}$ & 472 \\
GG & $41.74 \mathrm{BCDa}$ & $35.38 \mathrm{ABa}$ & $22.88 \mathrm{ABb}$ & 229 \\
GNG & $56.33 \mathrm{Aa}$ & $28.82 \mathrm{ABb}$ & $14.85 \mathrm{Bc}$ & 411 \\
NMG & $37.71 \mathrm{CDa}$ & $36.98 \mathrm{ABa}$ & $25.31 \mathrm{ABb}$ & 290 \\
NMNG & $51.72 \mathrm{ABa}$ & $31.04 \mathrm{ABb}$ & $17.24 \mathrm{ABc}$ & 260 \\
\hline Total & $54.62 \mathrm{ABa}$ & $26.15 \mathrm{Bb}$ & $19.23 \mathrm{ABb}$ & - \\
\hline
\end{tabular}

${ }^{1} \mathrm{CS}=$ Central stem ; B1= first branch ; B2= second branch.

${ }^{2} \mathrm{BG}=$ black grafted; $\mathrm{BNG}=$ black non-grafted; $\mathrm{WG}=$ white/black non-grafted; WNG= white/black non-grafted; GG = green grafted; GNG = green non-grafted; $\mathrm{NMG}=$ no mulch grafted; $\mathrm{NMNG}=$ no mulch non- grafted .

${ }^{3}$ Proportions followed by the same upper case letters, in the same column and the same lower case number on the same line do not differ by the Tukey test $(P<0.05)$. 
sated by fewer flowers on B1. Grafting increased the proportion of flowers on CS in the black and green polyethylene treatments. In addition with grafting the proportions of flowers on CS were greater than on B1 which were greater than the proportions on B2. Without grafting, the proportions of flowers on CS did not differ from the proportions on B1 and were greater than on B2. Thus the main flowering positions are CS for treatments with grafting and CS and B1 for treatments without grafting.

With grafting, the polyethylene treatments did not influence the proportion of fruits at the $\mathrm{CS}$ and $\mathrm{B} 1$ positions (Table 4). At the B2 position, the white/black cover and grafted treatment was superior to the green cover grafted treatment. Without grafting and at the CS position, the black cover treatment was inferior to the white/ black and no cover treatments. However, at position B1, the black non-grafted treatment was superior to the no cover non-grafted. At position B2 there was no effect of polyethylene cover type for ungrafted plants. Generally all plants performed similarly with a greater proportion of fruits on CS (33 to 65\%), intermediate on B1 (22 to $42 \%$ ) and less on B2 (7 to $25 \%$ ).

There was an association between the type of polyethylene cover and grafting and fruit classification (Table 5). The treatments with greater proportions of discard type fruits (between 37 and 55\%) and lower proportions of fruits in the superior categories (between 3 and $10 \%$ for extra A and $11 \%$ for extra AA) were black polyethylene cover grafted, green polyethylene cover grafted and no cover grafted, indicating that the grafting on 'Ikky'

Table 4 - Proportions of fruit for treatments and flowering positions and total number of fruits. Botucatu, SP, 1995.

\begin{tabular}{lcccc}
\hline \multirow{2}{*}{ Treatment } & \multicolumn{2}{c}{ Fruiting position } & \multicolumn{2}{c}{$\begin{array}{c}\text { Total number } \\
\text { of fruit }\end{array}$} \\
\cline { 2 - 5 } BG $^{2}$ & $\mathrm{CS}^{1}$ & $\mathrm{~B} 1$ & $\mathrm{~B} 2$ & 133 \\
BNG & $55.64 \mathrm{Aa}^{3}$ & $31.58 \mathrm{ABb}$ & $12.78 \mathrm{ABc}$ & 232 \\
WG & $33.19 \mathrm{Bab}$ & $42.24 \mathrm{Aa}$ & $24.57 \mathrm{Ab}$ & 208 \\
WNG & $49.52 \mathrm{Aa}$ & $30.29 \mathrm{ABb}$ & $20.19 \mathrm{Ab}$ & 199 \\
GG & $53.77 \mathrm{Aa}$ & $31.16 \mathrm{ABb}$ & $15.07 \mathrm{ABc}$ & 108 \\
GNG & $64.81 \mathrm{Aa}$ & $27.78 \mathrm{ABb}$ & $7.41 \mathrm{Bc}$ & $18.89 \mathrm{ABb}$ \\
NMG & $46.96 \mathrm{ABa}$ & $33.15 \mathrm{ABa}$ & $11.63 \mathrm{ABb}$ & 86 \\
NMNG & $65.12 \mathrm{Aa}$ & $23.25 \mathrm{Bb}$ & $14.74 \mathrm{AB} \mathrm{b}$ & 95 \\
\hline Total & $63.16 \mathrm{Aa}$ & $22.10 \mathrm{Bb}$ & - & 1242 \\
\hline
\end{tabular}

${ }^{1} \mathrm{CS}=$ Central stem ; B1 = first branch ; B2= second branch.

${ }^{2} \mathrm{BG}=$ black grafted; $\mathrm{BNG}=$ black non-grafted; $\mathrm{WG}=$ white/black non-grafted; $\mathrm{WNG}=$ white/black non-grafted; $\mathrm{GG}=$ green grafted; $\mathrm{GNG}$ = green non-grafted; $\mathrm{NMG}=$ no mulch grafted $\mathrm{NMNG}=$ no mulch non- grafted

${ }^{3}$ Proportions followed by the same upper case letters, in the same column and the same lower case number on the same line do not differ at $5 \%$.

Table 5 - Proportions of fruit classes for treatments and total number of fruits. Botucatu, SP, 1995.

\begin{tabular}{|c|c|c|c|c|c|c|}
\hline \multirow{2}{*}{ Treatment } & \multicolumn{5}{|c|}{ Commercial classification } & \multirow{2}{*}{ Total fruits } \\
\hline & Discarded & Special & Extra & Extra A & Extra AA & \\
\hline \multicolumn{7}{|c|}{ - \% of fruits -- } \\
\hline $\mathrm{BG}^{2}$ & $38.35 \mathrm{Aa}^{2}$ & $33.08 \mathrm{Aa}$ & $12.03 \mathrm{Ab}$ & $5.26 \mathrm{Bb}$ & $11.28 \mathrm{BCb}$ & 133 \\
\hline $\mathrm{BNG}$ & $4.33 \mathrm{Db}$ & $19.05 \mathrm{Aa}$ & $19.05 \mathrm{Aa}$ & $25.54 \mathrm{Aa}$ & $32.03 \mathrm{Aa}$ & 232 \\
\hline WG & 17.79 BCab & $28.85 \mathrm{Aa}$ & $12.50 \mathrm{Ab}$ & 19.23 Aab & $21.63 \mathrm{ABab}$ & 208 \\
\hline WNG & $10.00 \mathrm{CDb}$ & $26.00 \mathrm{Aa}$ & $18.50 \mathrm{Aab}$ & $24.50 \mathrm{Aa}$ & $21.00 \mathrm{ABab}$ & 199 \\
\hline GG & $55.56 \mathrm{Aa}$ & $27.78 \mathrm{Ab}$ & $8.33 \mathrm{Ac}$ & $3.70 \mathrm{Bc}$ & $4.63 \mathrm{Cc}$ & 108 \\
\hline GNG & $18.79 \mathrm{BCa}$ & $27.62 \mathrm{Aa}$ & $17.13 \mathrm{Aa}$ & $16.57 \mathrm{ABa}$ & $19.89 \mathrm{ABa}$ & 181 \\
\hline NMG & $37.21 \mathrm{ABa}$ & $29.07 \mathrm{Aab}$ & 19.77 Aab & $10.46 \mathrm{ABbc}$ & $3.49 \mathrm{Cc}$ & 86 \\
\hline NMNG & $10.53 \mathrm{CDb}$ & $31.58 \mathrm{Aa}$ & $18.95 \mathrm{Aab}$ & $16.84 \mathrm{ABab}$ & $22.10 \mathrm{ABab}$ & 95 \\
\hline Total & - & - & - & - & - & 1242 \\
\hline
\end{tabular}


squash was harmful to fruit quality, mainly because it caused shorter length and greater diameter (Table 2). However, this effect was less marked for the white/black polyethylene grafted treatment. For the treatments without grafting, comparing the polyethylene covers, the black treatment was outstanding and gave fewer discard quality fruits $(4 \%)$ and more fruits in the superior categories ( $25 \%$ extra $\mathrm{A}$ and $32 \%$ extra AA).

\section{REFERENCES}

ARAÚJO, J.A.C.; ARAÚJO, S.M.C.; CASTELLANE, P.D.; SIQUEIRA, C.E.M. Analisis de la productividad del pepino (Cucumis sativus L.), variedad "Vista alegre", utilizando cobertura de suelo con plásticos de colores diferentes. In: CONGRESO INTERNACIONAL DE PLASTICOS EN AGRICULTURA, 12., Granada, 1992. Proceedings. Granada. p.E108-113.

BHELLA, H.S. Effect of trickle irrigation and black mulch on growth, yield and mineral composition of watermelon. HortScience, v.23, p.123-125, 1988.

BONNANO, A.R.; LAMONT JR., W.J. Effect of polyenthylene mulches, irrigation method and row covers on soil and air temperature and yield of muskmelon. Journal of American Society for the Horticultural Science, v.112, p.735-738, 1987.

BRAVO, A.; RIPOLL, R. Efectos del uso de tunel y mulch plastico sobre la produccion de dos variedades de melon (Cucumis melo L.) Ciencia y Investigacion Agraria, v.13, p.193-199, 1986.

CAÑIZARES, K.A.L.; GOTO, R. Crescimento e produção de híbridos de pepino em função da enxertia. Horticultura Brasileira, v.16, p.110113, 1998.

CURI, P.R. Metodologia e análise da pesquisa em ciências biológicas. Botucatu: Tipomic, 1997. 263p

FARIAS-LARIOS, J.; GUZMAN, S.; MICHEL, A.C. Effect of plastic mulches on the growth and yield of cucumber in tropical region. Biological Agriculture and Horticulture, v.10, p.303-306, 1994.

HALLIDRI, M.; FERNANDEZ, J.A.; MARTINEZ, P.F.; CASTILLA, N. Comparison of the different mulching materials on the growth, yield and quality of cucumber (Cucumis sativus L.) Acta Horticulturae, n.559, p.49-54, 2001.
HARTMANN, H.T.; KESTER; D.E.; DAVIES, F.T. Plant propagation; principles and practices. 5.ed. New Jersey: Regent-Prentice Hall, 1991. $647 \mathrm{p}$.

HOYOS-ECHEBARRIA, P.; FERNANDEZ, J.A.; MARTINEZ, P.F.; CASTILLA, N. Influence of different rootstocks on the yield and quality of greenhouses grown cucumbers. Acta Horticulturae, n.559, p.139$143,2001$.

MAIERO, M.; SCHALES. F.D.; NG, T.J. Genotype and plastic mulch effects on earliness, fruit characteristics, and yield in muskmelon. HortScience, v.22, p.945-946, 1987.

MISCHAN, M.M.; PINHO, S.Z. Experimentação agronômica: dados não balanceados. Botucatu: Fundibio, 1996. 456p.

NIJS, A.P.M. The effect of grafting on growth and early production of cucumbers at low temperature. Acta Horticulturae, n.118, p.57-63, 1981.

PEREZ-AFONSO, J.L. Cultivo del pepino en invernadero. Madrid: Extension Agraria, 1984.

QUEZADA-MARTIN, M.R.; FLORES-VELÁSQUEZ, J.; IBARRAJIMÉNEZ, L. Integracion de tecnicas da plasticultura em el cultivo de pepino en la region noroeste de México. In: CONGRESO INTERNACIONAL DE PLASTICOS EN AGRICULTURA, 12., Granada, 1992. Proceedings. Granada, 1992. p.B173-180.

RUBEIZ, I.G.; NAJA, Z.U.; NIMAH, H.N. Enhancing late and early yield of greenhouse cucumber with plastic mulches. Biological Agriculture and Horticulture, v.8, p.67-70, 1991.

SALMAN, S.R.; BAKRI, M.O.; ABOU-HADID, A.F.; EL-BELTAGY, A.S. The effect of plastic mulch on the microclimate of plastic house. Acta Horticulturae, n.237, p.417-425, 1991.

TABER, H.G. Early muskmelon production with wavelength-selective and clear plastic mulches. HortTechnology, v.3, p.78-80, 1993.

WOLFE, D.W.; ALBRIGHT, L.D.; WYLAND, J. Modelling row covers effects on microclimate and yield: Growth response of tomato and cucumber. Journal of American Society for the Horticultural Science, v.114, p.562-568, 1989.

Received November 18, 2002

Accepted August 26, 2003 